\title{
Unconditional conservatism in Brazilian public companies and
}

\section{tax neutrality}

\author{
Juliana Pinhata Sanches do Vale
}

Universidade de São Paulo, Faculdade de Economia, Administração e Contabilidade de Ribeirão Preto, Departamento de Contabilidade, Ribeirão Preto, SP, Brazil

\section{Sílvio Hiroshi Nakao}

Universidade de São Paulo, Faculdade de Economia, Administração e Contabilidade de Ribeirão Preto, Departamento de Contabilidade, Ribeirão Preto, SP, Brazil

Received on 08.26.2015 - Desk acceptance on 10.20.2015 - $3^{\text {rd }}$ version approved on 11.21.2016

\section{ABSTRACT}

Law n. 11,638/2007 legitimized the International Financial Reporting Standards (IFRS) adoption process in Brazil and introduced an accounting system detached from tax purposes in the country. This law aims to reduce the influence of tax law on accounting standards and improve the quality of financial reporting, as IFRS are considered to be higher quality standards. International literature shows a reduction in earnings quality in environments where accounting and tax rules are strongly linked. Moreover, the influence of tax legislation on financial accounting is seen to encourage unconditional conservatism, a bias with no advantages for financial market efficiency. Thus, tax neutrality is expected to provide a more favorable institutional environment for quality financial reporting by detaching corporate accounting from tax accounting. In light of the above, this study aims to verify whether the advent of tax neutrality influences unconditional conservatism in Brazilian public companies. The methodology used involves panel data regressions. The sample consists of non-financial publicly-traded companies with information published in Economática covering 2002 to 2014. The results show differences in the relationship between taxation and financial reporting between firms that are subject to different levels of monitoring in the Brazilian stock market. Evidence of unconditional conservatism is only found in companies that are subject to greater market monitoring. In this group, it is observed that taxation does not induce unconditional conservatism in reported earnings, which is expected in a tax neutrality context.

Keywords: conservatism, tax neutrality, book-tax conformity, quality of accounting information, taxation. 


\section{INTRODUCTION}

Increased information quality after the adoption of International Financial Reporting Standards (IFRS) depends on at least two factors. First, there is the assumption that IFRS consist of a set of generally accepted accounting principles (GAAP) that lead to better quality financial reporting. Moreover, it should be considered that the accounting system is only one component of a country's institutional environment and is influenced by the set of incentives for financial disclosure that this environment provides (Soderstrom \& Sun, 2007).

It is unlikely that a single set of accounting rules incorporates similar qualitative attributes into the financial statements of heterogeneous economies. High quality accounting standards do not guarantee improved financial reporting, as the incentives and demand for information are more important than the imposition of external accounting standards in markets that seek better quality for their financial reports (Ball, Robin \& Wu, 2003). Differences between countries in terms of information quality may remain after IFRS adoption, as financial reports depend on the overall institutional context of firms, which includes the legal and political systems of the jurisdictions in which their financial statements are published (Soderstrom \& Sun, 2007). Financial reports are understood here as a set of financial statements published by a company in a particular period.

In Brazil, until 2007 accounting practice was intensely influenced by the system for calculating income tax, which led to a high level of book-tax conformity (BTC) in the country. Traditionally, Brazilian tax legislation influenced published financial statements, with statements for market disclosure purposes often being indistinct from statements for tax purposes (Lopes \& Walker, 2008).

BTC can be defined as the flexibility a firm has for reporting a different taxable income from accounting profit before income tax (Hanlon, Maydew \& Shevlin, 2008). The freedom of managers to release information on company performance without incurring tax penalties is the main benefit of less BTC in an economy (Atwood, Drake \& Myers, 2010).

Studies indicate that high levels of BTC can result in excessive conservatism in reported results, which minimizes earnings quality (Atwood et al., 2010; Hanlon et al., 2008). Soderstrom and Sun (2007) indicate that, among the advantages related to the change in accounting principles due to IFRS, the concept of "true and fair view" can reduce levels of book-tax conformity so that accounting better reflects the economic reality of firms.

Law n. 11,638/2007 (Brasil, 2007) stands out in this context for institutionalizing IFRS convergence in Brazil and detaching accounting standards from tax purposes, which led to the beginning of tax neutrality. Given that the literature suggests a loss in earnings quality when financial reporting is associated with tax rules (Hanlon, Laplante \& Shevlin, 2005), it is inferred that tax neutrality favors the reporting of higher quality accounting information. Lopes and Mosquera (2010) argue that IFRS adoption in Brazil must involve the independence of accounting in relation to taxation, with tax neutrality being a necessary condition for the convergence process in the country. This occurs since a reduction in conservative bias can mitigate the expropriation of wealth by controlling shareholders, as well as increasing the quality of financial information.

While conditional conservatism refers to the upfront recognition of economic losses that have not yet been incurred, in light of indications of negative results, unconditional conservatism involves the persistent undervaluation of net assets (Beaver \& Ryan, 2005). Among the incentives for practicing unconditional conservatism, Watts (2003a, 2003b) highlights the influences of tax legislation on financial accounting practices, as well as litigation costs and regulatory forces.

The advent of tax neutrality can increase the incentives for quality accounting information, since the link between tax and corporate norms imposes a dilemma on managers by attributing a dual role to accounting (Goncharov \& Zimmermann, 2005). Along with other attributes, it is hoped that tax neutrality provides Brazil with an institutional environment that is conducive to improved financial reporting, especially in entities that are subject to greater market monitoring or those with greater incentives for disclosure.

In this context, this article aims to verify whether the advent of tax neutrality influences unconditional conservatism in publicly-traded companies in Brazil. To achieve this objective, the study is based on the assumption that companies in the Brazilian stock market are subject to different levels of monitoring. Given the incentives for firms to engage in financial disclosure (Ball et al., 2003), it is inferred that different levels of monitoring can lead to heterogeneous accounting choices with regards to unconditional conservatism, even in the context of tax neutrality. 


\section{HYPOTHESIS DEVELOPMENT}

In code-law countries, litigation costs and tax influences usually promote excessive conservatism in accounting, as they encourage managers to restrict the concept of asset and carry out reductions and minimize the recognition of these elements in financial statements (Watts, 2003a, 2003b). Known as unconditional conservatism or balance sheet conservatism, this process implies undervaluing a firm's book-to-market (BTM) ratio (Gotti, 2008). Using historic cost as the recognition basis for projects with positive net present value and accelerated depreciation and amortization with regards to the estimated economic life of assets, are also examples of practices indicative of unconditional conservatism (Beaver \& Ryan, 2005).

Under this form of conservatism, the accounting value of net assets is underestimated due to predetermined aspects in the accounting process. For Ball and Shivakumar (2005), it involves a bias that withholds information from investors as it involves an adjustment carried out ex ante by the contracting parties. Thus, accounting does not react when new information occurs, as unconditional conservatism incorporates undervaluations up front, which means that its adoption does not present any advantages from a market efficiency point of view. In the literature, studies regarding the influence of tax legislation on financial accounting are recurrent (Ball \& Shivakumar, 2005; Beaver \& Ryan, 2005; Kim \& Jung, 2007; Watts, 2003a, 2003b).

Taxation is a relevant aspect of the quality of reported information, as a close link between accounting profit and taxable income reduces the ability for financial reporting to show the economic reality of an entity. Moreover, higher rates of income tax offer incentives for reducing taxable income, implying lower accounting profit in high BTC environments. This harms the financial market, as unlike shareholders and creditors, tax authorities are less adversely affected in cases of information asymmetry, since they have greater autonomy and powers to inspect firms (Soderstrom \& Sun, 2007).

Given that economic consequences and conflicts of interest are different in the firm/tax authority and firm/ investor contractual relationships, the aims of accounting profit and taxable income are different (Hanlon \& Heitzman, 2010; Shackelford, Slemrod \& Sallee, 2011). In light of this, tax neutrality is an important step towards producing more relevant accounting information, the more detachment between financial and tax accounting is formalized. In the international literature, Atwood et al. (2010) and Hanlon et al. (2008) find evidence that greater connections between accounting profit and taxable income reduce earnings quality. In Brazil, Cardoso, Costa, and Ávila (2016) find indications that the detachment of corporate from tax accounting is associated with an improvement in the quality of accounting information reported in the country after IFRS adoption.

BTC imposes a close relationship between accounting profit and taxable income. For this reason, strategies focused on reducing taxable income would result in lower accounting profits in environments with high levels of conformity. Given that companies would be concerned about disclosing large differences between accounting profit and taxable income in these environments, the option for managers would be to reduce accounting profit in order to minimize taxation costs. This relationship between accounting profit and taxable income creates a link between taxation and financial reporting in that the influence of taxation on corporate accounting tends to induce conservatism in reported earnings (Shackelford \& Shevlin, 2001).

Managers have incentives to behave conservatively in environments with higher levels of BTC, as a greater link between accounting profit and taxable income makes a reduction in the present value of tax expenses possible when accounting is conservative (Bushman \& Pietroski, 2006). Shackelford et al. (2011) add that the influence of taxation on earnings reported to the market is not desirable, since given the differences in the aims of financial and tax reporting, it is not unusual for the most informative measure of income for shareholders to be different from the most useful measure of income for tax authorities. Empirical evidence confirms that taxation induces unconditional conservatism in environments in which accounting profit and taxable income are strongly related (Kim \& Jung, 2007; Lara, Osma \& Penalva, 2009; Qiang, 2007). Hanlon et al. (2008) find indications that these circumstances reduce earnings quality.

In Brazil, tax neutrality allows IFRS adoption to present no impacts on taxable income calculations. Therefore, it is to be expected that the introduction of an accounting system that is detached from tax purposes can minimize the influence of tax planning on conservative accounting choices.

Despite detachment between accounting profit and taxable income being possible due to Law n. 11,638/2007 (Brasil, 2007), an absence of firm economic incentives may not lead to the changes expected from BTC in certain companies. 
Interests in aggressive tax planning practices and the cost of control inherent to detachment from tax norms can encourage managers to keep financial accounting linked to tax legislation. Guenther, Maydem, and Nutter (1997) conclude that even with the existence of different recognition methods in determining accounting profit and taxable income, some managers are resistant to recording transactions that increase accounting profit without increasing taxable income or that increase deductible expenses without increasing accounting expenses.

The flexibility of IFRS offers a certain degree of discretion to managers, in that accounting choices can be guided by procedures imposed by tax legislation, if this fits the manager's interest. Gee, Haller, and Nobes (2010) verify that taxes influence reporting under IFRS and part of this influence can result in costs that are necessary for managing two parallel accounting systems, one for the purposes of reporting to investors and creditors and the other for tax purposes.

Given that companies from the same country have different incentives with regards to financial reporting (Ball et al., 2003), the advent of tax neutrality can present different impacts on firms that are subject to heterogeneous economic incentives, especially with regards to capital market monitoring.
In this study, the Bovespa index (Ibovespa) is used as a proxy for greater market monitoring, as it features a portfolio that is representative of the most highly tradable assets that most represent the Brazilian stock market. In comparison with other publicly-traded companies in Brazil, those that compose the Ibovespa have a greater number of investors monitoring their financial reports, which implies greater demand for quality accounting information. Providing better information helps companies to remain within the portfolio, which suggests that the Ibovespa can be used as a proxy for identifying companies that are subject to greater stock market monitoring.

In light of the above, it is assumed that firms that are subject to greater market monitoring have more economic incentives to abandon BTC and present less unconditional conservatism in reported income from 2008 onwards, as proposed by the research hypothesis.

$\mathrm{H}_{1}$ : unconditional conservatism in the income reported by Brazilian publicly-traded companies that are subject to greater stock market monitoring reduces after the advent of tax neutrality, with the passing of Law n. 11,638/2007 (Brasil, 2007).

\section{METHODOLOGICAL PROCEDURES}

\subsection{Description of the Econometric Model Used}

The empirical investigation of the relationship between unconditional conservatism and tax neutrality is conducted via the analysis of panel data. The econometric model proposed derives from that used by Qiang (2007) in order to adapt a model that is already consolidated in the literature to the specific characteristics of the study.

The proxy used to measure unconditional conservatism in this study is a modification of the bias component proposed by Beaver and Ryan (2000). The authors distinguish between two sources of variation for the BTM ratio, called "bias" and "lag" in accounting recognition. Both behaviors are related to the recognition process in accounting, however, bias is a persistent phenomenon, while lag is a temporary phenomenon (Beaver \& Ryan, 2000). The BTM ratio is the ratio between a firm's book value and market value.

According to Beaver and Ryan (2000), "bias" in accounting recognition refers to the book value being persistently lower (greater) than the market value of a firm, which makes the BTM ratio persistently lower (higher) than 1 . This distortion known as bias would result in the joint effect of interaction between characteristics of the accounting process, such as conservatism and historic cost, and the economic environment of a firm. As for the distortion identified as "lag", this would derive from the fact that unexpected economic gains are recognized in book value over time, instead of immediately, which would make the BTM ratio temporarily lower than its average in the short term.

The use of a proxy based on BTM aims to reflect the effect of conservatism in book value per share (BVPS). Thus, market value is used as a reference to measure conservatism as a persistent bias that reduces the book value of equity (Lara et al., 2009). The nonpersistent component refers to the lag in accounting recognition. Beaver and Ryan (2000) find evidence that the persistent bias component is associated with measures of unconditional conservatism, while lag is not.

In the Beaver and Ryan (2000) model, expressed in equation 1, conservatism is measured by a firm's fixed 
effects (intercept) in a regression that considers the BTM ratio as a dependent variable and return as an independent variable. The fixed effect aims to capture the time variation in the recognition of gains and losses in the BVPS (bookvalue) of each firm. Current returns are a proxy for new information and the coefficients of returns capture the lag with which accounting incorporates the information already priced by the market. The under or overvaluation of book value not explained by returns is captured by the firm intercept, which measures the persistent bias. This bias measured by the intercept is understood as a measure of unconditional conservatism when it presents a result lower than 1 .

$$
B T M_{j t}=\propto_{j}+\sum_{T=0}^{6} \beta_{T} R E T_{j t-T}+\mu_{j t}
$$

in which $B T M_{j t}$ is the BTM ratio for firm $j$ at the end of period $t$ (Book Value per Share / Closing Quotation); and $R E T_{j i}$ is the rate of return (In (Quotation / Quotation $\left._{(\mathrm{t}-1)}\right)$ ) for firm $j$ in period $t$, in which $t$ varies from 1 to 6 , indicating that current returns are considered as well as the returns occurring in the last six years. In equation 1 , the BTM is regressed by current and lagged returns, using the ordinary least squares (OLS) estimator and controlling for the fixed effects of the firms.

The "fixed effect" identified by the $\alpha_{j}$ intercept is expected to be equal to the firm's BTM ratio in the isolated presence of bias, that is, in the absence of lags in accounting recognition (Beaver \& Ryan, 2000). This means that the intercept shows what the average BTM of the firms would be if the accounting timelily recognized the same economic gains already priced by the market.

It is known, however, that the accounting recognition process is linked to norms that aim to protect investors. For this reason, share prices can incorporate news on the outlook for future earnings that the accounting is not yet able to recognize. Given that returns are a proxy for new information, the $\beta_{\mathrm{T}}$ coefficients capture the lag in accounting recognition in equation 1 , that is, the portion of the variation in share price not yet recognized in the accounting.

The model restricts the coefficients of returns so that they capture symmetrical lags between good and bad news, with asymmetric lags and persistent bias captured by the firm intercept (Qiang, 2007). This causes noise in the results, given that the intercept captures both the unconditional bias and the conditional bias not captured by the coefficients of returns (Lara et al., 2009; Qiang, 2007).

As in equation 2, the adaptation proposed by Qiang (2007) includes a dummy variable for return in the model that allows the coefficients to be asymmetric in relation to positive and negative returns. With the inclusion of this variable, the return terms incorporate symmetric and asymmetric lags and the firm intercept $\left(\alpha_{j}\right)$ only captures the unconditional bias, thus being a more accurate proxy for unconditional conservatism (Lara et al., 2009; Qiang, 2007).

In this sense, after controlling for market performance, from the moment of incorporating lagged returns in the model, the closer the value of the estimated coefficient $\hat{\alpha}_{\text {. }}$ is to 1 , the closer the company's book value, represented by BVPS, is to its market value (Qiang, 2007). It should be reiterated that, although the specific intercept of firms can incorporate a large increase $\left(\hat{\alpha}_{j}\right.$ greater than 1), it is the persistent bias for reduction (intercept lower than 1) that is associated with unconditional conservatism.

$$
C S V_{j}=1-\hat{\alpha}_{j} ; \text { with } \hat{\alpha}_{j} \text { given by: }
$$

$$
B T M_{j t}=\propto_{j}+\sum_{T=0}^{6} \beta_{T} R E T_{j t-T}+\sum_{T=0}^{6} \gamma_{T}^{0} D R_{j t-T} * R E T_{j t-T}+\mu_{j t}
$$


in which $C S V_{j}$ is the book-value-based measure of unconditional conservatism for firm $j$ over the time series; $B T M_{j t}$ is the BTM ratio for firm $j$ at the end of period $t$; $R E T_{j t}$ is the rate of return for firm $j$ in period $t$, and $D R_{j t}$ is a dummy variable that takes the value 1 if $R E T_{j t}$ is negative and 0 otherwise. In equation 2 the BTM is regressed by return and by the interactive dummies for return using the OLS estimator and controlling for the fixed effects of the firms.

In the model, an estimated coefficient $\left(\hat{\alpha}_{j}\right)$ that is lower than 1 is understood as being a persistent bias for reducing the book value in relation to the economic value of a firm (Beaver \& Ryan, 2000). The bias is considered persistent, as even the incorporation of current and lagged returns is not able to explain the undervaluation of BVPS in relation to its market price. Therefore, a lower coefficient, but closer to 1 , indicates that the accounting system more completely incorporates a firm's economic value represented by the price; that is, the accounting is less conservative.

\subsubsection{Unconditional conservatism model and the influence of taxation.}

Qiang (2007) finds evidence that the possibility of reducing taxation costs resulting from BTC leads to unconditional conservatism in reported income. To analyze the relationship between unconditional conservatism and BTC, the author includes into equation 2 a proxy that measures the possibility of reducing taxation costs (BTC variable), which results in equation 3.

$$
\begin{gathered}
C S V_{j}=1-\hat{\alpha}_{j} ; \text { with } \hat{\alpha}_{j} \text { given by: } \\
B T M_{j t}=\propto_{j}+\sum_{T=0}^{6} \beta_{T} R E T_{j t-T}+\sum_{T=0}^{6} \gamma_{T}^{0} D R_{j t-T} * R E T_{j t-T}+\sum_{T=0}^{6} \gamma_{T} C C F_{j} * D R_{j t-T} * R E T_{j t-T}+\mu_{j t}
\end{gathered}
$$

in which $C S V_{j}$ is a book-value-based measure of unconditional conservatism for firm $j$ over the time series; $B T M_{j t}$ is the BTM ratio for firm $j$ at the end of period $t$; $R E T_{j t}$ is the rate of return for firm $j$ in period $t: D R_{j t}$ is a dummy variable that takes the value 1 if $R E T_{j i}$ is negative and 0 otherwise, and $B T C_{j}$ is the proxy of BTC for firm $j$, calculated according to equation 4 . In equation $3, \mathrm{BTM}$ is regressed by return, by the interactive dummies for return, and by the interactions between the BTC variable and the dummies for return. The OLS estimator is used, controlling for the fixed effects of the firms.

In the regression, the measure of conservatism is given by $C S V_{j}=1-\hat{\alpha}_{j}$, when is lower than 1 . The $B T C_{j}$ variable captures the level of conformity between accounting profit and taxable income and is given by the $\hat{\beta}_{1 j}$ coefficient, estimated by equation 4 .

$$
I T_{j t}=\beta_{0 j}+\beta_{1 j} D F_{j t}+\varepsilon_{j, t}
$$

in which $\hat{\beta}_{1 j}$ is the connection between accounting profit and taxable income (BTC measure) for firm $j$ in the period analyzed; $D F_{j t}$ is the taxation expense [revenue or expense for income tax and social security contributions (IT\&SS)] for firm $j$ in year $t$, and $I T_{j t}$ is the current income tax [current income tax and social security contributions (IncTax)]. In equation 4, the current income tax is regressed by the taxation expense using the OLS estimator. The estimated coefficient $\hat{\beta}_{1 j}$ measures the connection between accounting profit and taxable income, used as a proxy for BTC.

According to Qiang (2007), a stronger connection between accounting profit and taxable income represents a greater level of BTC and indicates a higher possibility of reducing taxation costs when reducing accounting profit. Given that the expected reduction in taxation costs increases the closer the relationship is between accounting and tax systems, the connection between accounting profit and taxable income acts as a proxy for the possibility of reducing taxation costs and is a measure of BTC (Qiang, 2007).

Equation 5 substitutes the specific intercept of the firms $\left(\propto_{j}\right)$ for the $B T C_{j}$ variable in equation 3 with the aim of verifying whether BTC influences the measure of persistent bias. The intention behind this substitution is to verify whether the relationship between accounting profit and taxable income (BTC measure) leads to unconditional conservatism $\left(\propto_{j}\right)$ in the firms analyzed. 
Given that a lower firm intercept indicates greater unconditional conservatism in reported results, the coefficients of the variables indicative of factors that lead to the phenomenon are expected to be negative and statistically significant (Qiang, 2007). This verification occurs in statistical software by applying the OLS estimator for equation 5 and selecting the "without constant" option.

$$
\begin{aligned}
B T M_{j t}= & \propto B T C_{j}+\sum_{T=0}^{6} \beta_{T} R E T_{j t-T}+\sum_{T=0}^{6} \gamma_{T}^{0} D R_{j t-T} * R E T_{j t-T} \\
& +\sum_{T=0}^{6} \gamma_{T} B T C_{j} * D R_{j t-T} * R E T_{j t-T}+\mu_{j t}
\end{aligned}
$$

in which $B T C_{j}$ is the BTC proxy for firm $j$ calculated in accordance with equation $4 ; B T M_{j t}$ is the BTM ratio for firm $j$ at the end of period $t ; R E T_{j t}$ is the rate of return for firm $j$ in period $t$, and $D R_{j t}$ is a dummy variable that takes the value 1 if $R E T_{j t}$ is negative and 0 otherwise. In equation $5, \mathrm{BTM}$ is regressed by the BTC proxy, by return, by the interactive dummies for return, and by the interactions between the BTC variable and the return dummies. The OLS estimator is used in a regression generated without the interception term (regression that passes through the origin).

The results from the regression without the constant (equation 5) allow for comparison between the estimated coefficient for the BTC variable and the intercept estimated for the firms by equation 3. A negative and statistically significant coefficient indicates that the BTC variable negatively influences a firms' BTM, suggesting that the connection between accounting profit and taxable income leads to unconditional conservatism, measured by the persistent reduction bias.

\subsubsection{Unconditional conservatism model proposed.}

As proposed by the research objective, this study intends to verify whether the advent of tax neutrality influences unconditional conservatism in publicly-traded Brazilian companies. To adapt the model from Qiang (2007) to the context studied, the periods before and after the advent of tax neutrality are analyzed simultaneously in the same regression. For this, equations 3 to 5 are adjusted by the inclusion of a dummy variable for year (DY) that takes the value 1 for 2008 onwards and 0 otherwise. These adaptations result in equations 6 and 7, which follow the same operationalization standards as equations 3 and 5 , respectively.

In the model proposed by equations 6 and 7, it is possible to analyze the relationship between BTC and unconditional conservatism over the complete study horizon. The inclusion of the dummy variable DY derives from the effects that can arise regarding the firms' BTC, given the advent of tax neutrality from 2008 onwards.

$$
\begin{gathered}
C S V_{j}=1-\hat{\alpha}_{j} \text { with } \hat{\alpha}_{j} \text { given by: } \\
B T M_{j t}=\alpha_{j}+\sum_{T=0}^{6} \beta_{T} R E T_{j t-T}+\sum_{T=0}^{6} \gamma_{T}^{0} D R_{j t-T} * R E T_{j t-T}+\sum_{T=0}^{6} \gamma_{T} B T C_{j} \\
* D R_{j t-T} * R E T_{j t-T}+\delta_{1} D Y_{j t}+\sum_{T=0}^{6} \delta_{T} D Y_{j t} * D R_{j t-T} * R E T_{j t-T} \\
+\sum_{T=0}^{6} \delta_{T} D Y_{j t} * B T C_{j} * D R_{j t-T} * R E T_{j t-T}+\mu_{j t}
\end{gathered}
$$


in which $C S V_{j}$ is the book-value-based unconditional conservatism measure for firm $j$ over the course of the time series; $B T M_{j t}$ is the BTM ratio for firm $j$ at the end of period $t ; R E T_{j t}$ is the rate of return for firm $j$ in period $t$; $D R_{j t}$ is a dummy variable that takes the value 1 if $R E T_{j t}$ is negative and 0 otherwise; $B T C_{j}$ is the BTC proxy for firm $j$ calculated in accordance with equation 4 , and is an yearly dummy indicative of tax neutrality, which takes the value 1 for the periods from 2008 onwards and 0 otherwise.

$$
\begin{aligned}
B T M_{j t}= & \propto B T C_{j}+\sum_{T=0}^{6} \beta_{T} R E T_{j t-T}+\sum_{T=0}^{6} \gamma_{T}^{0} D R_{j t-T} * R E T_{j t-T} \\
& +\sum_{T=0}^{6} \gamma_{T} B T C_{j} * D R_{j t-T} * R E T_{j t-T}+\delta_{1} D Y_{j t} \\
& +\sum_{T=0}^{6} \delta_{T} D Y_{j t} * D R_{j t-T} * R E T_{j t-T} \\
& +\sum_{T=0}^{6} \delta_{T} D Y_{j t} * B T C_{j} * D R_{j t-T} * R E T_{j t-T}+\mu_{j t}
\end{aligned}
$$

in which $B T C_{j}$ is the BTC proxy for firm $j$ calculated in accordance with equation $4 ; B T M_{j t}$ is the BTM ratio for firm $j$ at the end of period $t ; R E T_{j t}$ is the rate of return for firm $j$ in period $t ; D R_{j t}$ is a dummy variable that takes the value 1 if $R E T_{j t}$ is negative and 0 otherwise; and $D Y_{j t}$ is an yearly dummy variable indicative of tax neutrality, which takes the value 1 for the periods from 2008 onwards and 0 otherwise.

In light of the above, the econometric tests are carried out for the periods before (up to 2007) and after (from 2008 onwards) the advent of tax neutrality [Law n. 11,638/2007 (Brasil, 2007)] via equation 3 and 5. This segregation allows for the relationship between BTC and unconditional conservatism to be observed separately in the periods before and after the advent of tax neutrality. Equations 6 and 7 are used in the tests that include the complete study horizon.

Finally, the influence of tax neutrality over unconditional conservatism is analyzed separately for companies participating and those not participating in the Ibovespa. As proposed by the research hypothesis, a reduction is expected in unconditional conservatism in the income reported by the companies that are subject to greater stock market monitoring after the advent of tax neutrality, with the passing of Law n. 11,638/2007 (Brasil, 2007).

\subsection{Database}

The data were gathered from the Economática software. The initial database is comprised of all the non-financial companies that had active shares on the São Paulo Stock, Commodities, and Futures Exchange (BM\&FBOVESPA) on April 15, 2015. We chose to capture the data relative to the most liquid shares of each company, according to the trading record on December 31,2014. With the filter established, 355 active firms were identified.

The research horizon covers 2002 to 2014 , so that it contemplates the periods before and after the beginning of tax neutrality in Brazil. In Economática the following data were gathered: (i) BVPS, (ii) closing quotation, (iii) IT\&SS, and (iv) IncTax. The data are on a yearly basis, adjusted for inflation, extracted from the consolidated statements, and refer to December 31 of each financial year. The closing quotation is adjusted for proceeds, including dividends, and considers lags of up to 20 days in order to reduce data lacking for low liquidity companies.

With the data gathered, the BTM (Book Value per 
Share/Closing Quotation) and return [In (Quotation/ Quotation $\left._{(\mathrm{t}-1)}\right)$ ] variables were calculated. Observations with negative BTM were removed from the database. The same procedure was carried out with the localized observations based on three standards deviations above and below the average, as they were identified as outliers that could cause distortions in the results analysis.

\subsection{Sample Description}

The first sample treatment aims to maintain only companies for which it was possible to calculate the BTC proxy for both periods, before and after tax neutrality, in the database. Each firm's BTC in each period was estimated in accordance with the adaptation of the time series regression proposed by Qiang (2007), presented in equation 4.

Two databases were initially elaborated. The first refers to the periods from 2002 to 2007, before tax neutrality, and the second contemplates the periods from 2008 to
2014, after the advent of neutrality [Law n. 11,638/2007 (Brasil, 2007)]. Segregation of the database is necessary for carrying out the regressions that aim to estimate the level of BTC of the firms in each one of the periods analyzed.

With the regressions carried out, only the companies for which it was possible to calculate the BTC proxy for both periods were kept. As a result of unavailable or insufficient data for carrying out these regressions, the sample was reduced to 232 companies. Out of these 232, 61 opened up or closed capital during the study horizon, and were therefore excluded from the sample. Finally, insufficient data for calculating the return (RET) and BMT variables for the 35 firms were identified. In light of this, the final sample is comprised of 136 companies.

Finally, in order for the research hypothesis tests to be carried out, the final sample with 136 firms is separated into two subsamples representative of companies that are subject to more or less market monitoring, depending on participation or not in the Ibovespa.

\section{RESULTS ANALYSIS}

\subsection{Descriptive Statistics}

To meet the proposal of the research hypothesis, the descriptive statistics are presented separately for the samples representative of companies that are subject to different levels of stock market monitoring: companies participating in the Ibovespa and companies not participating in the Ibovespa.

In accordance with Table 1 comparing the periods before and after tax neutrality, it is verified that the average for the BTC variable reduces for the group of companies that do not belong to the Ibovespa. 
Table 1 Descriptive statistic: variables from the unconditional conservatism model

\begin{tabular}{|c|c|c|c|c|c|c|}
\hline & \multicolumn{6}{|c|}{ Period before tax neutrality (2002 to 2007) } \\
\hline & \multicolumn{2}{|c|}{ BTC } & \multicolumn{2}{|c|}{ BTM } & \multicolumn{2}{|c|}{ RET } \\
\hline & Not Ibovespa & Ibovespa & Not Ibovespa & Ibovespa & Not Ibovespa & Ibovespa \\
\hline Mean & 0.53 & 0.46 & 1.53 & 1.20 & 0.30 & 0.26 \\
\hline Median & 0.26 & 0.43 & 1.20 & 0.87 & 0.23 & 0.25 \\
\hline Minimum & -4.69 & -5.22 & 0.01 & 0.03 & -0.93 & -0.83 \\
\hline Maximum & 4.90 & 4.00 & 5.52 & 5.05 & 2.40 & 1.72 \\
\hline Standard deviation & 1.50 & 1.75 & 1.28 & 1.09 & 0.54 & 0.39 \\
\hline C.V. & 2.83 & 3.77 & 0.84 & 0.90 & 1.78 & 1.47 \\
\hline Bias & 0.26 & -1.56 & 1.14 & 1.56 & 0.83 & 0.45 \\
\hline Ex. kurtosis & 1.87 & 4.31 & 0.61 & 2.07 & 1.20 & 1.97 \\
\hline $5 \%$ percentile & -1.88 & -5.02 & 0.17 & 0.14 & -0.48 & -0.39 \\
\hline $95 \%$ percentile & 3.82 & 3.33 & 4.20 & 3.88 & 1.25 & 0.87 \\
\hline Interquartile coefficient & 1.39 & 0.70 & 1.68 & 1.19 & 0.66 & 0.40 \\
\hline \multicolumn{7}{|c|}{ Period after tax neutrality (2008 to 2014) } \\
\hline Mean & 0.45 & 0.61 & 1.18 & 0.79 & -0.02 & -0.03 \\
\hline Median & 0.39 & 0.77 & 0.91 & 0.72 & 0.01 & -0.02 \\
\hline Minimum & -0.79 & -0.30 & 0.00 & 0.04 & -1.99 & -1.54 \\
\hline Maximum & 2.11 & 1.34 & 5.47 & 3.71 & 2.14 & 1.43 \\
\hline Standard deviation & 0.47 & 0.46 & 0.97 & 0.61 & 0.63 & 0.46 \\
\hline C.V. & 1.04 & 0.74 & 0.82 & 0.78 & 27.85 & 13.29 \\
\hline Bias & 0.31 & -0.45 & 1.72 & 1.50 & -0.23 & -0.28 \\
\hline Ex.kurtosis & 0.25 & -0.93 & 3.43 & 3.71 & 0.86 & 0.77 \\
\hline $5 \%$ percentile & -0.15 & -0.26 & 0.20 & 0.07 & -1.16 & -0.85 \\
\hline $95 \%$ percentile & 1.08 & 1.22 & 3.19 & 1.86 & 1.03 & 0.68 \\
\hline Interquartile coefficient & 0.81 & 0.77 & 1.06 & 0.79 & 0.69 & 0.50 \\
\hline
\end{tabular}

BTM = book-to-market; C.V. = coefficient of variation; BTC = book-tax conformity; lbovespa = Bovespa index; RET =return .

Source: Prepared by the authors.

In Table 1, for the Ibovespa group, the means and medians of these variables were greater in the period after the start of tax neutrality. It is noted that the standard deviation reduces in both subsamples, which indicates a reduction in the spread of the variable between the periods analyzed.

In comparing the period after in relation to the period before the advent of tax neutrality, no significant differences were verified between the medians of the BTC variable, for the two subsamples, as shown in Table 2. Due to the advent of tax neutrality from 2008 onwards, a significant difference was expected for this variable between the two periods, at least for the companies subject to greater stock market monitoring.

The mean of the BTM variable presented a fall between the periods, both for the companies not participating in the Ibovespa and for those participating. It is noted that the mean and the median of the BTM variable are lower, in both periods, for the subsample representative of the companies that are under greater market monitoring.

It bears mentioning that, although a BTM lower than 1 may be associated with excessively conservative accounting choices, this pattern is preferable to a BTM that is persistently greater than 1 , under the assumption that the market is able to adequately measure firm value. The data in Table 1 indicate that the firms subject to less monitoring tend to present an average BTM that is persistently greater than 1 in both the analysis periods.

A significant difference is observed when comparing the BTC of companies participating in the Ibovespa with that of companies not participating, in the two periods analyzed, as shown in Table 2. This indicates a difference in the connection between accounting profit and taxable income between companies subject to different levels of Brazilian stock market monitoring.

The results in Table 2 confirm that there is a significant difference between the medians of the BTM variable for the two subsamples when the period after is compared to the period before tax neutrality. Moreover, there is a significant difference between the medians of the BTM of companies participating in the Ibovespa compared with those not participating, in the two analysis periods. With regards to return (RET), it is verified that the average for the variable is greater for the companies not participating in the Ibovespa, in both periods. 
Table 2 Results from the tests of difference

\begin{tabular}{|c|c|c|c|}
\hline & \multicolumn{3}{|c|}{ Wilcoxon rank sum tests (p two-tailed) } \\
\hline & \multicolumn{3}{|c|}{ (null hypothesis: the two medians are equal) } \\
\hline & \multicolumn{3}{|c|}{ Test variable } \\
\hline & BTM & RET & BTC \\
\hline \multicolumn{4}{|l|}{ Before vs. after } \\
\hline Ibovespa & $0.000340^{* * *}$ & $0.000000^{* * *}$ & 0.349788 \\
\hline Not Ibovespa & $0.000685^{* * *}$ & $0.000000^{* * *}$ & 0.491633 \\
\hline \multicolumn{4}{|c|}{ Ibovespa vs. not Ibovespa } \\
\hline Before & $0.002826^{* * *}$ & 0.915465 & $0.007464^{* * *}$ \\
\hline After & $0.000000^{* * *}$ & $0.044509^{* *}$ & $0.000001^{* * *}$ \\
\hline
\end{tabular}

BTM = book-to-market; BTC = book-tax conformity; Ibovespa = Bovespa index; RET = return.

***, **, *: statistical significance to $1 \%, 5 \%$, and $10 \%$, respectively.

Source: Prepared by the authors.

\subsection{Results for the Unconditional Conservatism Model}

In accordance with the research hypothesis, we sought to verify if unconditional conservatism reduces in the companies subject to greater stock market monitoring after the advent of tax neutrality. For this reason, the results are presented separately between companies participating in the Ibovespa and companies not participating in the Ibovespa.

The correlation between return and BTC is presented in Table 3 and does not indicate problems of multicollinearity between the explanatory variables in the model.

Table 3 Correlation coefficients between the RET and BTC variable

\begin{tabular}{|c|c|c|}
\hline \multicolumn{3}{|c|}{$\begin{array}{c}\text { Ibovespa } \\
\end{array}$} \\
\hline \multicolumn{3}{|c|}{$5 \%$ critical value (bilateral) $=0.0947$ for $n=429$} \\
\hline \multicolumn{3}{|c|}{ BTC } \\
\hline \multicolumn{3}{|c|}{0.0269} \\
\hline- & 1 & BTC \\
\hline & 1 & \\
\hline \multicolumn{3}{|c|}{$5 \%$ critical value (bilateral) $=0.0536$ for $n=1339$} \\
\hline CCF & RET & \\
\hline 1 & -0.0095 & BTC \\
\hline- & 1 & RET \\
\hline
\end{tabular}

BTC = book-tax conformity; Ibovespa = Bovespa index; RET = return.

Source: Prepared by the authors.

\subsubsection{Results for the companies participating in the Ibovespa.}

Considering the complete study horizon, the average intercept of the firms ("const" in Table 4 - Results for equation 6) is lower than 1 (0.746), indicating that, on average, the book value of the firms analyzed is lower than their market value, which is consistent with the presence of unconditional conservatism in reported earnings.

In the econometric model used, unconditional conservatism is represented by a persistent reduction bias (value lower than 1) in the average coefficient for the firms estimated based on equation 6 . In this equation, the measure of unconditional conservatism is given by $C S V_{j}=1-\hat{\alpha}_{j}$ from which it is concluded that, on average, the book value of the firms that comprise the sample is $25.4 \%\left(C S V_{j}=1-0.746\right)$ lower than their market value.

With the aim of confirming indications of the direct influence of BTC over unconditional conservatism, we observe the results generated by equation 7 . By substituting the specific intercept of the firms for the BTC proxy in equation 6 , the intention is to observe the effect of BTC over unconditional conservatism in a specific way. In this model it is expected that the coefficients of the variables indicative of factors that lead to unconditional conservatism are negative and statistically significant, given that a lower firm intercept indicates more conservative reported earnings (Qiang, 2007). 
The results for equation 7 (Table 4) do not present any indications that taxation is related with unconditional conservatism in the companies that comprise the sample, since the coefficient of the BTC variable for equation 7 is positive (0.347, as in Table 4). Unlike what the research hypothesis proposes, the results for equations 6 and 7 , presented in Table 4, mean that it cannot be stated that unconditional conservatism in the earnings reported by publicly-traded Brazilian companies subject to greater stock market monitoring reduces after the advent of tax neutrality, with the passing of Law n. 11,638/2007 (Brasil, 2007).

Table 4 Results from the unconditional conservatism model for the Ibovespa sample: complete study horizon

\begin{tabular}{|c|c|c|c|c|c|c|c|c|c|}
\hline \multicolumn{10}{|c|}{ Book-value-based measure of unconditional conservatism } \\
\hline \multicolumn{10}{|c|}{ Companies participating in the Ibovespa } \\
\hline \multicolumn{10}{|c|}{ Dependent variable $=$ BTM } \\
\hline & Results for ec & quation 6 & & & & Results for & equation 7 & & \\
\hline $\mathbf{R}^{2}$ within & 0.6483 & & & & $\mathbf{R}^{2}$ adjusted & 0.6940 & & & \\
\hline$p(F)$ & 0.0000 & & & & $\mathbf{p}(\mathbf{F})$ & 0.0000 & & & \\
\hline Variable & Coefficient & $\begin{array}{l}\text { Standard } \\
\text { error }\end{array}$ & t-ratio & $\mathbf{p}$ & & Coefficient & $\begin{array}{l}\text { Standard } \\
\text { error }\end{array}$ & t-ratio & $\mathbf{p}$ \\
\hline const & 0.746 & 0.249 & 3.001 & $0.003^{* * *}$ & BTC & 0.347 & 0.088 & 3.943 & $0.000^{* * *}$ \\
\hline RETt & -0.302 & 0.141 & -2.139 & $0.034 * *$ & RETt & -0.234 & 0.216 & -1.083 & 0.280 \\
\hline RETt_1 & -0.402 & 0.134 & -3.005 & $0.003^{* * *}$ & RETt_1 & -0.346 & 0.210 & -1.649 & 0.101 \\
\hline RETt_2 & -0.345 & 0.159 & -2.178 & $0.031^{* *}$ & RETt_2 & -0.489 & 0.186 & -2.624 & $0.009^{* * *}$ \\
\hline RETt_3 & 0.013 & 0.162 & 0.081 & 0.935 & RETt_3 & -0.104 & 0.154 & -0.679 & 0.498 \\
\hline RETt_4 & 0.001 & 0.159 & 0.008 & 0.994 & RETt_4 & -0.017 & 0.150 & -0.114 & 0.909 \\
\hline RETt_5 & 0.083 & 0.095 & 0.871 & 0.385 & RETt_5 & -0.069 & 0.150 & -0.463 & 0.644 \\
\hline RETt_6 & 0.088 & 0.066 & 1.329 & 0.185 & RETt_6 & 0.318 & 0.135 & 2.346 & $0.020^{* *}$ \\
\hline DR_RETt & -1.645 & 0.839 & -1.961 & $0.051^{*}$ & DR_RETt & -1.283 & 1.027 & -1.249 & 0.213 \\
\hline DR_RETt_1 & -0.533 & 0.308 & -1.731 & $0.085^{*}$ & DR_RETt_1 & 0.278 & 0.845 & 0.329 & 0.743 \\
\hline DR_RETt_2 & -1.447 & 0.623 & -2.321 & $0.021^{* *}$ & DR_RETt_2 & -1.764 & 0.607 & -2.907 & $0.004^{* * *}$ \\
\hline DR_RETt_3 & -1.039 & 0.416 & -2.497 & $0.013^{* *}$ & DR_RETt_3 & -2.242 & 0.626 & -3.583 & $0.000^{* * *}$ \\
\hline DR_RETt_4 & -0.804 & 0.438 & -1.837 & $0.068^{*}$ & DR_RETt_4 & -2.777 & 0.554 & -5.010 & $0.000^{* * *}$ \\
\hline DR_RETt_5 & -0.163 & 0.157 & -1.040 & 0.300 & DR_RETt_5 & -1.215 & 0.428 & -2.841 & $0.005^{* * *}$ \\
\hline DR_RETt_6 & -0.018 & 0.160 & -0.115 & 0.909 & DR_RETt_6 & -0.864 & 0.355 & -2.432 & $0.016^{* *}$ \\
\hline BTC_DR_RETt & -0.496 & 0.626 & -0.792 & 0.429 & BTC_DR_RETt & 0.357 & 1.052 & 0.339 & 0.735 \\
\hline BTC_DR_RETt_1 & -0.394 & 0.389 & -1.013 & 0.312 & BTC_DR_RETt_1 & -0.590 & 0.822 & -0.718 & 0.474 \\
\hline BTC_DR_RETt_2 & 0.242 & 0.265 & 0.911 & 0.363 & BTC_DR_RETt_2 & 0.892 & 0.614 & 1.452 & 0.148 \\
\hline BTC_DR_RETt_3 & 0.027 & 0.188 & 0.146 & 0.884 & BTC_DR_RETt_3 & 0.934 & 0.640 & 1.458 & 0.146 \\
\hline BTC_DR_RETt_4 & -0.154 & 0.277 & -0.558 & 0.578 & BTC_DR_RETt_4 & 0.578 & 0.390 & 1.481 & 0.140 \\
\hline BTC_DR_RETt_5 & 0.003 & 0.069 & 0.039 & 0.969 & BTC_DR_RETt_5 & 0.477 & 0.268 & 1.783 & $0.076^{*}$ \\
\hline BTC_DR_RETt_6 & 0.051 & 0.049 & 1.035 & 0.302 & BTC_DR_RETt_6 & 0.158 & 0.193 & 0.817 & 0.415 \\
\hline DY & -0.407 & 0.114 & -3.578 & $0.000^{* * *}$ & DY & 0.461 & 0.108 & 4.267 & $0.000^{* * *}$ \\
\hline DY_DR_RET & 1.464 & 0.807 & 1.814 & $0.071^{*}$ & DY_DR_RET & 0.159 & 0.995 & 0.159 & 0.874 \\
\hline DY_DR_RETt_1 & 0.251 & 0.291 & 0.862 & 0.390 & DY_DR_RETt_1 & -0.331 & 0.868 & -0.382 & 0.703 \\
\hline DY_DR_RETt_2 & 1.035 & 0.563 & 1.837 & $0.068^{*}$ & DY_DR_RETt_2 & 1.746 & 0.728 & 2.400 & $0.017^{* *}$ \\
\hline DY_DR_RETt_3 & -0.234 & 0.433 & -0.541 & 0.589 & DY_DR_RETt_3 & 2.500 & 0.675 & 3.707 & $0.000^{* * *}$ \\
\hline DY_DR_RETt_4 & -0.241 & 0.433 & -0.556 & 0.579 & DY_DR_RETt_4 & 2.647 & 0.625 & 4.238 & $0.000^{* * *}$ \\
\hline DY_DR_RETt_5 & -0.954 & 0.252 & -3.780 & 0.132 & DY_DR_RETt_5 & 1.356 & 0.520 & 2.608 & $0.010^{* * *}$ \\
\hline DY_DR_RETt_6 & -1.053 & 0.300 & -3.511 & 0.171 & DY_DR_RETt_6 & -0.075 & 0.462 & -0.163 & 0.871 \\
\hline DY_BTC_DR_RETt & -0.351 & 0.676 & -0.520 & 0.604 & DY_BTC_DR_RETt & 0.039 & 1.148 & 0.034 & 0.973 \\
\hline DY_BTC_DR_RETt_1 & 0.626 & 0.380 & 1.647 & 0.101 & DY_BTC_DR_RETt_1 & 1.010 & 0.983 & 1.027 & 0.305 \\
\hline DY_BTC_DR_RETt_2 & 0.024 & 0.338 & 0.072 & 0.943 & DY_BTC_DR_RETt_2 & -0.529 & 0.874 & -0.605 & 0.546 \\
\hline DY_BTC_DR_RETt_3 & 0.479 & 0.380 & 1.263 & 0.208 & DY_BTC_DR_RETt_3 & -1.864 & 0.845 & -2.206 & $0.028^{* *}$ \\
\hline DY_BTC_DR_RETt_4 & 0.882 & 0.422 & 2.088 & $0.038^{* *}$ & DY_BTC_DR_RETt_4 & -0.433 & 0.617 & -0.702 & 0.484 \\
\hline DY_BTC_DR_RETt_5 & 0.939 & 0.347 & 2.707 & $0.007^{* * *}$ & DY_BTC_DR_RETt_5 & -0.158 & 0.552 & -0.286 & 0.775 \\
\hline DY_BTC_DR_RETt_6 & 0.791 & 0.318 & 2.486 & $0.014^{* *}$ & DY_BTC_DR_RETt_6 & 0.491 & 0.519 & 0.946 & 0.345 \\
\hline
\end{tabular}

$C S V_{j}=1-\hat{\alpha}_{j}$; with $\hat{\alpha}_{j}$ given by equations 6 and 7 .

Ibovespa = Bovespa index.

***, **, *: statistical significance to $1 \%, 5 \%$, and $10 \%$, respectively.

Source: Prepared by the authors. 
4.2.2 Results for the companies not participating in the Ibovespa.

As shown in Table 5, the average intercept of the firms ("const" Table 5 - Results for equation 6) is significantly greater than 1 (2.311), indicating that, on average, the book value of the firms is greater than their market value, which is incompatible with the presence of unconditional conservatism.

Table 5 Results from the unconditional conservatism model for the non-Ibovespa sample: complete study horizon

\begin{tabular}{|c|c|c|c|c|c|c|c|c|c|}
\hline \multicolumn{10}{|c|}{ Book-value-based measure of unconditional conservatism } \\
\hline \multicolumn{10}{|c|}{ Companies not participating in the Ibovespa } \\
\hline \multicolumn{10}{|c|}{ Dependent variable $=$ BTM } \\
\hline & Results for & quation 6 & & & & Results for & equation 7 & & \\
\hline $\mathbf{R}^{2}$ within & 0.4270 & & & & $\mathbf{R}^{2}$ adjusted & 0.5779 & & & \\
\hline $\mathbf{p}(\mathbf{F})$ & 0.0000 & & & & $\mathbf{p}(\mathbf{F})$ & 0.0000 & & & \\
\hline Variable & Coefficient & $\begin{array}{c}\text { Standard } \\
\text { error }\end{array}$ & t-ratio & $\mathbf{p}$ & & Coefficient & $\begin{array}{l}\text { Standard } \\
\text { error }\end{array}$ & t-ratio & p \\
\hline const & 2.311 & 0.357 & 6.471 & $0.000^{* * *}$ & CCF & -0.035 & 0.187 & -0.187 & 0.852 \\
\hline RETt & -0.762 & 0.206 & -3.700 & $0.000 * * *$ & RETt & -0.105 & 0.218 & -0.481 & 0.631 \\
\hline RETt_1 & -0.796 & 0.171 & -4.661 & $0.000^{* * *}$ & RETt_1 & 0.016 & 0.206 & 0.078 & 0.938 \\
\hline RETt_2 & -0.523 & 0.132 & -3.964 & $0.000^{* * *}$ & RETt_2 & 0.137 & 0.194 & 0.707 & 0.480 \\
\hline RETt_3 & -0.295 & 0.188 & -1.565 & 0.119 & RETt_3 & 0.191 & 0.175 & 1.093 & 0.275 \\
\hline RETt_4 & -0.276 & 0.128 & -2.159 & $0.032 * *$ & RETt_4 & 0.084 & 0.169 & 0.499 & 0.618 \\
\hline RETt_5 & -0.186 & 0.128 & -1.453 & 0.147 & RETt_5 & 0.116 & 0.164 & 0.710 & 0.478 \\
\hline RETt_6 & -0.086 & 0.099 & -0.870 & 0.385 & RETt_6 & 0.134 & 0.169 & 0.789 & 0.431 \\
\hline DR_RETt & 0.003 & 0.380 & 0.007 & 0.995 & DR_RETt & -0.408 & 0.576 & -0.709 & 0.479 \\
\hline DR_RETt_1 & -2.252 & 1.433 & -1.572 & 0.117 & DR_RETt_1 & -5.581 & 0.907 & -6.154 & $0.000^{* * *}$ \\
\hline DR_RETt_2 & -1.081 & 1.215 & -0.890 & 0.374 & DR_RETt_2 & -4.965 & 0.991 & -5.011 & $0.000^{* * *}$ \\
\hline DR_RETt_3 & -0.681 & 0.745 & -0.914 & 0.362 & DR_RETt_3 & -4.412 & 1.120 & -3.941 & $0.000^{* * *}$ \\
\hline DR_RETt_4 & 0.180 & 0.611 & 0.294 & 0.769 & DR_RETt_4 & -1.753 & 0.638 & -2.749 & $0.006^{* * *}$ \\
\hline DR_RETt_5 & 0.586 & 0.396 & 1.477 & 0.141 & DR_RETt_5 & -0.465 & 0.515 & -0.903 & 0.367 \\
\hline DR_RETt_6 & 0.335 & 0.309 & 1.085 & 0.279 & DR_RETt_6 & -0.793 & 0.493 & -1.609 & 0.109 \\
\hline BTC_DR_RETt & 1.209 & 0.662 & 1.828 & 0.609 & BTC_DR_RETt & 0.214 & 0.770 & 0.278 & 0.781 \\
\hline BTC_DR_RETt_1 & 0.134 & 2.485 & 0.054 & 0.957 & BTC_DR_RETt_1 & 0.610 & 1.437 & 0.425 & 0.671 \\
\hline BTC_DR_RETt_2 & -1.208 & 2.145 & -0.563 & 0.574 & BTC_DR_RETt_2 & 0.534 & 1.503 & 0.355 & 0.723 \\
\hline BTC_DR_RETt_3 & 0.199 & 1.121 & 0.178 & 0.859 & BTC_DR_RETt_3 & 1.553 & 1.758 & 0.883 & 0.378 \\
\hline BTC_DR_RETt_4 & 0.233 & 0.226 & 1.032 & 0.303 & BTC_DR_RETt_4 & 0.376 & 0.437 & 0.860 & 0.390 \\
\hline BTC_DR_RETt_5 & 0.476 & 0.316 & 1.508 & 0.133 & BTC_DR_RETt_5 & 0.320 & 0.591 & 0.541 & 0.589 \\
\hline BTC_DR_RETt_6 & -1.359 & 0.347 & -3.916 & $0.000^{* * *}$ & BTC_DR_RETt_6 & -0.839 & 0.807 & -1.040 & 0.299 \\
\hline DY & -0.999 & 0.205 & -4.861 & $0.000^{* * *}$ & DY & 0.825 & 0.170 & 4.854 & $0.000^{* * *}$ \\
\hline DY_DR_RET & -0.100 & 0.452 & -0.221 & 0.825 & DY_DR_RET & -0.056 & 0.657 & -0.084 & 0.933 \\
\hline DY_DR_RETt_1 & 2.151 & 1.306 & 1.647 & 0.101 & DY_DR_RETt_1 & 5.503 & 0.881 & 6.246 & $0.000^{* * *}$ \\
\hline DY_DR_RETt_2 & 0.851 & 1.178 & 0.723 & 0.470 & DY_DR_RETt_2 & 4.740 & 0.962 & 4.927 & $0.000^{* * *}$ \\
\hline DY_DR_RETt_3 & 0.205 & 0.674 & 0.304 & 0.762 & DY_DR_RETt_3 & 3.878 & 1.115 & 3.477 & $0.001^{* * *}$ \\
\hline DY_DR_RETt_4 & -0.041 & 0.770 & -0.053 & 0.958 & DY_DR_RETt_4 & 1.376 & 0.679 & 2.027 & $0.043^{* *}$ \\
\hline DY_DR_RETt_5 & -0.464 & 0.370 & -1.255 & 0.210 & DY_DR_RETt_5 & -0.112 & 0.578 & -0.195 & 0.846 \\
\hline DY_DR_RETt_6 & -0.245 & 0.340 & -0.720 & 0.472 & DY_DR_RETt_6 & 0.518 & 0.504 & 1.028 & 0.305 \\
\hline DY_BTC_DR_RETt & -0.720 & 0.706 & -1.020 & 0.309 & DY_BTC_DR_RETt & -0.563 & 1.061 & -0.531 & 0.596 \\
\hline DY_BTC_DR_RETt_1 & 0.386 & 2.634 & 0.146 & 0.884 & DY_BTC_DR_RETt_1 & -0.533 & 1.509 & -0.353 & 0.724 \\
\hline DY_BTC_DR_RETt_2 & 1.523 & 2.281 & 0.668 & 0.505 & DY_BTC_DR_RETt_2 & -0.572 & 1.560 & -0.367 & 0.714 \\
\hline DY_BTC_DR_RETt_3 & 0.307 & 1.050 & 0.292 & 0.770 & DY_BTC_DR_RETt_3 & -0.782 & 1.821 & -0.429 & 0.668 \\
\hline DY_BTC_DR_RETt_4 & -0.273 & 0.457 & -0.598 & 0.550 & DY_BTC_DR_RETt_4 & 0.482 & 0.762 & 0.632 & 0.528 \\
\hline DY_BTC_DR_RETt_5 & -0.362 & 0.439 & -0.825 & 0.410 & DY_BTC_DR_RETt_5 & 0.665 & 0.793 & 0.839 & 0.402 \\
\hline DY_BTC_DR_RETt_6 & 1.356 & 0.458 & 2.959 & $0.003^{* * *}$ & DY_BTC_DR_RETt_6 & 0.858 & 0.918 & 0.935 & 0.351 \\
\hline
\end{tabular}

$\mathrm{CSV}_{j}=1-\hat{\alpha}_{j}$; with $\hat{\alpha}_{j}$ given by equations 6 and 7 .

Ibovespa = Bovespa index.

***, **, *: statistical significance to $1 \%, 5 \%$, and $10 \%$, respectively.

Source: Prepared by the authors. 
In order to verify whether BTC leads to a persistent reduction bias in the $\mathrm{BTM}$ ratio for the firms that comprise the sample, we observed the estimated results for equation 7. According to Table 5, it cannot be concluded that BTC leads to a lower average intercept for the firms, since although the coefficient of the BTC variable is negative $(-0.035$ in the results for equation 7$)$, it is not statistically significant. Therefore, from the results it cannot be stated whether tax neutrality influences unconditional conservatism in the companies not participating in the Ibovespa, as there is no evidence that BTC leads to this phenomenon in the companies that comprise the sample.

\subsubsection{Summary of the results.}

In Table 6 the results for equations 3 and 6 are presented for the periods before and after tax neutrality, for each one of the subsamples. Also, the main results for equations 5 and 7 are presented again for the complete study horizon.

With regards to the companies that are subject to greater stock market monitoring, no indications of unconditional conservatism are found in the period before the beginning of tax neutrality (average intercept of 1.171 , therefore greater than 1 ). Worth noting is that the estimated value for the average intercept of the firms in the period is instigating, since despite unconditional conservatism not providing relevant content for investors (Ball \& Shivakumar, 2005), the persistent overvaluation of market value may still adversely affect contractual efficiency in the financial markets.

Tabela 6 Summary of the results for the unconditional conservatism model

\begin{tabular}{|c|c|c|c|c|}
\hline \multicolumn{5}{|c|}{ Book-value-based measure of unconditional conservatism } \\
\hline \multicolumn{5}{|c|}{ Dependent variable $=$ BTM } \\
\hline \multicolumn{5}{|c|}{ Companies participating in the Ibovespa } \\
\hline Variable & Model (equations) & 2002 to 2007 & 2008 to 2014 & Complete period \\
\hline \multicolumn{5}{|l|}{ Coefficients } \\
\hline Average intercept of the firms (const) & 3 and 6 & $1.171^{* *}$ & 0.263 & $0.745^{* * *}$ \\
\hline BTC & 5 and 7 & $0.378^{* * *}$ & $0.520^{* * *}$ & $0.346^{* * *}$ \\
\hline \multicolumn{5}{|l|}{ Interpretation } \\
\hline Indications of unconditional conservatism & 3 and 6 & No & No & Yes \\
\hline BTC leads to reduction bias in the intercept & 5 and 7 & No & No & No \\
\hline \multicolumn{5}{|c|}{ Companies not listed on the Ibovespa } \\
\hline \multicolumn{5}{|l|}{ Coefficients } \\
\hline Average intercept of the firms (const) & 3 and 6 & 1.598 & $1.072^{* * *}$ & $2.310^{* * *}$ \\
\hline BTC & 5 and 7 & 0.283 & $0.554 * * *$ & -0.035 \\
\hline \multicolumn{5}{|l|}{ Interpretation } \\
\hline Indications of unconditional conservatism & 3 and 6 & No & No & No \\
\hline BTC leads to reduction bias in the intercept & 5 and 7 & No & No & No \\
\hline
\end{tabular}

BTM = book-to-market; BTC = book-tax conformity; lbovespa = Bovespa index.

***, **, *: statistical significance to $1 \%, 5 \%$, and $10 \%$, respectively.

Source: Prepared by the authors.

If assets are correctly priced by the market and the share price reflects all of the information available regarding a firm at any given moment, a book value greater than market value may indicate that the accounting information does not incorporate an economic loss that is already priced by investors. Unlike what occurred in the period before the advent of tax neutrality, a bias for increasing the average BTM of the firms participating in the Ibovespa is not verified when observing the complete study horizon.

With regards to the influence of taxation on unconditional conservatism, it is noted that BTC does not lead to a persistent reduction bias in the earnings reported by the companies participating on the Ibovespa, as seen in the results for the complete study horizon. Although the estimated value for the average intercept of the firms $(0.745)$ is consistent with the presence of unconditional conservatism, this reduction bias is not caused by the relationship between accounting profit and taxable income, which is expected in a tax neutrality context.

As for the value found for the average intercept of the firms in the period after the advent of tax neutrality, this is not statistically significant and it cannot be concluded whether there are indications of unconditional conservatism in the earnings reported from 2008 to 2014 by the companies participating in the Ibovespa.

For the companies subject to less market monitoring, no indications of unconditional conservatism are verified in any of the periods observed and no conclusions can be made regarding the influence of tax neutrality on this phenomenon during the study horizon. It bears mentioning that, on average, the book value of the firms 
that comprise the sample is greater than their market value in all of the analysis periods. Unlike the companies participating in the Ibovespa, those that do not participate in the index maintain a bias for increasing the BTM ratio after IFRS convergence in Brazil, from 2008 onwards.

\section{CONCLUSION}

This paper aimed primarily to verify whether the advent of tax neutrality influences unconditional conservatism in publicly-traded Brazilian companies.

In order to achieve this objective, we started from the assumption that companies are subject to different levels of stock market monitoring in Brazil. As the incentives for financial disclosure by firms can lead to heterogeneous accounting choices, the tests were carried out separately for companies subject to more or less market monitoring, using participation or not in the Ibovespa as a proxy.

The results found for the relationship between taxation and financial reporting, in the context of tax neutrality, are not very clear. By observing the firms subject to greater market monitoring, it cannot be stated that unconditional conservatism in reported earnings reduces after tax neutrality. Among the companies subject to less monitoring, no indications of unconditional conservatism are verified, but a persistent bias for increasing the average BTM of the firms is.

For the companies listed in the Ibovespa, the results for the complete study horizon indicate that unconditional conservatism is not caused by the relationship between accounting profit and taxable income, which is expected in a tax neutrality context. This can be considered as the main evidence found in the study.

With regard to the quality of earnings reported in Brazil, unconditional conservatism is only verified for the companies participating in the Ibovespa. It bears mentioning that although a persistent bias for reducing the BTM ratio is undesirable, a bias for increasing adversely affects financial market efficiency even more, which was observed for the firms subject to less market monitoring.

The results found for the companies not listed in the Ibovespa is similar to the findings of Santos and Cavalcante (2014), who did not find any evidence that IFRS adoption has produced effects on unconditional conservatism in publicly-traded Brazilian companies. Similarly, Dutra and
Costa (2014) conclude that there is no conservatism in Brazil, since they find indications of upfront recognition of gains in relation to losses. Alves and Martinez (2014) investigated the effects of Brazil's adhesion to IFRS on unconditional conservatism in large Brazilian companies, but did not find any indications of a change in the level of conservatism in the earnings reported by these entities between 2005 and 2010.

With regards to unconditional conservatism, no studies were found in Brazil for comparing the results of this study.

The main limitation of this study lies in the restriction with regards to generalization of the findings. The validity of the relationships studied is limited to the study sample and no inferences can be made for the rest of the population. It is emphasized, however, that the reduced sample derives from the absence of data necessary for the variables that comprise the econometric model.

Another limitation derives from the criterion for classifying firms as participating in the Ibovespa or not and this considering a theoretical portfolio of assets in the index only for the period from May to August of 2015.

Moreover, the econometric modeling used does not consider conservatism to be endogenously determined depending on unexpected returns, with this being a recently discussed issue in studies that involve estimates of conditional and unconditional conservatism.

Over the course of the article, new research opportunities in the accounting-tax field were detected. The relationship between taxation and earnings quality could be investigated via analysis of the content of explanatory notes, which may present subtle but useful information on tax planning strategies and a firm's relationship with deferred taxes. Moreover, new models could be used with the aim of observing, from other perspectives, the influence of taxation on financial reporting. 


\section{REFERENCES}

Alves, J. S., \& Martinez, A. L. (2014). Efeitos da adoção das IFRS no conservadorismo contábil das sociedades de grande porte. Advances in Scientific and Applied Accounting, 7(2), 224-243.

Atwood, T. J., Drake, M. S., Myers, L. A. (2010). Book-tax conformity, earnings persistence and the association between earnings and future cash flows. Journal of Accounting and Economics, 50(1), 111-125.

Ball, R., \& Shivakumar, L. (2005). Earnings quality in U.K. private firms: comparative loss recognition timeliness. Journal of Accounting and Economics, 39, 83-128.

Ball, R., Robin, A., \& Wu, J. S. (2003). Incentives versus standards: properties of accounting income in four East Asian countries. Journal of Accounting and Economics, 36(1), 235-270.

Beaver, W..H., \& Ryan, S. G. (2000). Biases and lags in book value Cardoso, T. A. L., Costa, P. S., \& Ávila, L. A. C. (2016). A persistência do book-tax diferences nas companhias abertas brasileiras. Anais do Congresso Anpcont, Ribeirão Preto, SP, Brasil. Retrieved from http://congressos.anpcont.org.br/x/ anais/files/2016-05/cue279.pdf.

Dutra, E. S., \& Costa, F. M. (2014). A relação entre gerenciamento de resultados e conservadorismo contábil em companhias abertas brasileiras. Advances in Scientific and Applied Accounting, 7(1), 149-170.

Gee, M., Haller, A., \& Nobes, C. (2010). The influence of tax on IFRS consolidated statements: the convergence of Germany and the UK. Accounting in Europe, 7(1), 97-122.

Goncharov, L., \& Zimmermann, J. (2005). Earnings management when incentives compete: the role of tax accounting in Russia [Working Paper]. Social Science Research Network. Retrieved from https://ssrn.com/abstract=622640 or http://dx.doi. org/10.2139/ssrn.622640.

Gotti, G. (2008). Conditional conservatism in accounting: new measure and tests of determinants [Working Paper]. Social Science Research Network. Retrieved from http://ssrn.com/ abstract $=1105083$ or http://dx.doi.org/10.2139/ssrn.1105083.

Guenther, D. A., Maydew, E. L., \& Nutter, S. E (1997). Financial reporting, tax costs, and book-tax conformity. Journal of Accounting and Economics, 23(3), 225-248.

Hanlon, M., \& Heitzman, S. (2010). A review of tax research. Journal of Accounting and Economics, 50(2), 127-178.

Hanlon, M., Laplante, S. K., \& Shevlin T. (2005). Evidence for the possible information loss of conforming book income and taxable income. Journal of Law and Economics, 48(3), 407-442.

Hanlon, M., Maydew, E. L., \& Shevlin T. (2008). An unintended consequence of book-tax conformity: a loss of earnings informativeness. Journal of Accounting and Economics, 46(2), 294-311.

Kim, B., \& Jung, K. (2007). The influence of tax costs on accounting conservatism [Working Paper]. Social Science Research Network: Retrieved from http://ssrn.com/ and their effects on the ability of the book-to-market ratio to predict book return on equity. Journal of Accounting Research, $38(1), 127-148$.

Beaver, W. H., \& Ryan, S. G. (2005). Conditional and unconditional conservatism: concepts and modeling. Review of Accounting Studies, 10(2), 269-309.

Brasil (2007). Lei $n^{\circ} 11.638$, de 28 de dezembro de 2007. Altera e revoga dispositivos da Lei no 6.404, de 15 de dezembro de 1976, e da Lei $n^{\circ} 6.385$, de 7 de dezembro de 1976. Brasília, DF: Diário Oficial da União.

Bushman; R. M., \& Piotroski, J. D. (2006). Financial reporting incentives for conservatism accouting: the influence of legal and political institutions. Journal of Accounting and Economics, 42(1), 107-148. abstract=987441 or http://dx.doi.org/10.2139/ssrn.987441.

Lara, J. M. G., Osma, B. G., \& Penalva, F. (2009). The economic determinants of conditional conservatism. Journal of Business Finance and Accounting, 36(3), 336-372.

Lopes, A. B., \& Walker, M. (2008). Firm-level incentives and the informativeness of accounting reports: an experiment in Brazil [Working Paper]. Social Science Research Network. Retrieved from http://ssrn.com/abstract=1095781 or http:// dx.doi.org/10.2139/ssrn.1095781.

Lopes, A. B., \& Mosquera, R. Q. (2010). O direito contábil fundamentos conceituais, aspectos da experiência brasileira e implicações: Controvérsias jurídico-contábeis (aproximações e distanciamentos), 1(1), 56-81.

Qiang, X. (2007). The effects of contracting, litigation, regulation, and tax costs on conditional and unconditional conservatism: cross-sectional evidence at the firm level. The Accounting Review, 82(3), 759-796.

Santos, M. A. C., \& Cavalcante, P. R. N. (2014). O efeito da adoção dos IFRS sobre a relevância informacional do lucro contábil no Brasil. Revista Contabilidade \& Finanças, 25(66), 228-241.

Shackelford, D. A., \& Shevlin, T. (2001). Empirical tax research in accounting. Journal of Accounting and Economics, 31(1), 321-387.

Shackelford, D. A., Slemrod, J., \& Sallee, J. (2011). Financial reporting, tax, and real decisions: toward a unifying framework. International Tax and Public Finance, 18(4), 461494.

Soderstrom, N. S., \& Sun, K. J. (2007). IFRS adoption and accounting quality: a review. European Accounting Review, 16(4), 675-702.

Watts, R. L. (2003a). Conservatism in accounting. Part I: explanations and implications. Accounting Horizons, 17(3), 207-221.

Watts, R. L. (2003b). Conservatism in accounting. Part II: evidence and research opportunities. Accounting Horizons, 17(4), 287-301.

\section{Correspondence address:}

Juliana Pinhata Sanches do Vale

Universidade de São Paulo, Faculdade de Economia, Administração e Contabilidade de Ribeirão Preto, Departamento de Contabilidade Avenida Bandeirantes, 3900 - CEP: 14040-900

Monte Alegre - Ribeirão Preto - SP - Brasil

Email: julianasanches@fearp.usp.br 